\title{
The Geology, Geochemistry and Mineralogy of Beryl Mineralization in Zabara Area, South Eastern Desert, Egypt
}

\author{
Khaleal F. M. ${ }^{1}$, El-Bialy M. Z. ${ }^{2}$, Saleh G. M. ${ }^{1 *}$, Ibrahim W. S. ${ }^{1}$, El Dawy M. N. ${ }^{1}$ \\ ${ }^{1}$ Nuclear Materials Authority, P.O. Box 530, El Maadi, Cairo, Egypt \\ ${ }^{2}$ Faculty of Science, Port Said University; Port Said, Egypt
}

\begin{abstract}
*Corresponding Author: Saleh G. M., Nuclear Materials Authority, P.O. Box 530, El Maadi, Cairo, Egypt E-mail:drgehad_m@yahoo.com
\end{abstract}

\begin{abstract}
This study deals with the geology, geochemistry and mineralogy of the beryl mineralization in the Zabara area, South Eastern Desert (SED), Egypt. The rock units which are exposed in Zabara area granite gneisses, serpentinites, mélange rocks, metavolcanics and post granite dykes and veins. The rock units which are exposed in the beryl mines area at Wadi (W.) Zabara area are gneiss rocks and schist rocks as well as quartz veins. The contact between the gneisses and overlying schists is thrust contact trending $N N W$ and dipping $38^{\circ}$ toward NE. The schists represent the most predominant rock unite within Zabara beryl mines area, covering about $1.0 \mathrm{Km}^{2}$. It is composed mainly of different varieties of schists such as hornblende schist, quartzo-feldspathic schist and garnet biotite schist. In some of these schists (phlogopite schist), beryl crystals are disseminated. The beryl mineralization is restricted to the contact between the schist rocks and gneiss rocks. These schists are dissected by number of quartz veins; some of them are beryl bearing veins, whereas the others are barren. The beryl crystals are of small size, fractured and pale green in color. The good quality of beryl with green grass color (emerald) could be found in phlogopite schist.
\end{abstract}

The beryl crystals were confirmed by both X-Ray Diffraction (XRD) and Scan Electron Microscope (SEM). The XRD study revealed that in the case of the quartz hosted beryl it displayed beryl peaks as the major phase with minor amount of quartz peaks suggesting that the beryl crystals were fractured and filled by quartz. The beryl peaks are associated with muscovite peaks in case of phlogopite schist hosted beryl suggesting that the beryl crystals were fractured and filled by schist.

The environmental scan electron microscope (ESEM) study (EDAX) analysis of the beryl crystals in W. Zabara area displayed the appearance of $\mathrm{Na}, \mathrm{Mg}, \mathrm{Al}, \mathrm{Si}, \mathrm{K}, \mathrm{Ca}$ and Fe elements. Beryl of W. Zabara area has high values of $\mathrm{Mg}, \mathrm{K}$ and $\mathrm{Fe}$. Ti appeared in quartz-hosted beryl, whereas Ni appeared in phlogopite schist-hosted beryl.

The spectrometric study within W. Zabara area revealed that the gneiss rocks have K\% contents of (3.89\%). This is higher than the schist rocks (1.8\%). The gneiss rocks have eU and eTh contents as (10.05 \& 33.47) respectively; these values are higher than those of schists (1,8\& 3.05) respectively. The average of eU/eTh ratio for gneisses $(0.32)$ is lower than the average value of eU/eTh ratio for schists (1.01). The gneiss rocks at $W$. Zabara area are relatively abnormal case as the corresponding crustal average values.

The gneiss rocks of W. Zabara area have higher contents of $\mathrm{Al}_{2} \mathrm{O}_{3}, \mathrm{MgO}, \mathrm{Na}_{2} \mathrm{O}$ and $\mathrm{P}_{2} \mathrm{O}_{5}$ than gneisses rocks at Abu Rusheid area (the highest radioactive anomaly in Egypt). On the other hand, Abu Rusheid gneiss rocks have higher values of $\mathrm{SiO}_{2}, \mathrm{TiO}_{2}, \mathrm{~K}_{2} \mathrm{O}$ and $\mathrm{MnO}$ than those in $\mathrm{W}$. Zabara area. The schist rocks have higher values of $\mathrm{SiO}_{2}, \mathrm{~K}_{2} \mathrm{O}$ and $\mathrm{TiO}_{2}$ than those in Wadi El Gemal area. On the other hand, Wadi El Gemal schist rocks have higher values of $\mathrm{Al}_{2} \mathrm{O}_{3}, \mathrm{MgO}, \mathrm{Na}_{2} \mathrm{O}, \mathrm{P}_{2} \mathrm{O}_{5}$ and $\mathrm{MnO}$ than those in Zabara area.

Keywords: W. Zabara, Geology, Geochemistry, Mineralogy, Beryl, Mineralization, Egypt.

\section{INTRODUCTION}

The basement rocks in Egypt covering about100, $000 \mathrm{~km}^{2}$ at the northwestern part of the ArabianNubian Shield. These basement rocks comprise four main rock sequences, gneiss assemblage (oldest), island arc assemblage, ophiolite assemblage and syn- and post tectonic intrusions (youngest) (Abd Naby et al., 2000; Abd Naby and Frisch, 2002).

Zabara area is located at the northern part of the south Eastern Desert (30 km southwest Marsa Alam coastal City). This area is characterized by several amounts of ancient beryl mine workings. 
Beryl is a beryllium alumino-silicate mineral with the chemical formula $\mathrm{Be}_{3} \mathrm{Al}_{2}\left(\mathrm{Si}_{6} \mathrm{O}_{18}\right)$. Beryl in ordinary case is colorless but the presence of various trace impurities gives the gem quality; as an example emerald is the green grass variety of beryl due to the presence of $\mathrm{Cr}^{+2}$. Beryl is the main source of beryllium $(\mathrm{Be})$ element that used to in many industrial applications. The emeralds of the South Eastern Desert of Egypt have been exploited by the world's first emerald mines (Harrell, 2004). A huge mine dumps resulted from the ancient mine working by The Romans whose were interest to extensive mine workings in the Eastern Desert of Egypt.

W. Zabara beryl mines area is included within a beryl belt known as Zabara - Um Addebaa (Z-UD) belt. This belt extends about $32 \mathrm{~km}$ in NW-SE direction with about $9 \mathrm{~km}$ width. This belt comprise the most ancient emerald mine in the world; this is Sikait mine.

Few studies were done on the beryl at Z-UD belt e.g. Hassan and El-Shatoury (1976), Grubessi et al. (1990), Grundman, Grundman and Morteani (1993) Abdalla and Mohamed (1999), Omar (2001), Harrel (2004) and Khaleal (2016).

The main objective of the present work is to study the geology, geochemistry and mineralogy of beryl mineralization in Zabara area.

\section{MeThOdS OF STUdY}

The extensive field studies were followed up with detailed laboratory studies as follows:

1. Petrographic study was carried out through the microscopic investigation of about 15 thin sections representing the different rocks exposed in the study area.

2. Geochemical study was carried out through the following: (a) Determinations of major oxides for ten (10) samples of all rock units exposed in the study area (five samples from gneisses and five samples from schists) by using wet chemical analytical technique Shapiro, L. and Brannock, W. W., (1962): Rapid analysis of silicate, carbonate and phosphate rocks, U. S. Geol. Surv. Bull, 114 A, 56 P. with \pm 2 wt. \% error for most oxides. These analyses were carried out at Nuclear Materials Authority laboratories. (b) XRF analysis (Trace elements) for the same ten (10) samples of gneisses and schists by using X-ray fluorescence (XRF) techniques using Philips X-Unique II spectrometer (PW-1510) with automatic sample changer. The analytical error is estimated about \pm $5 \mathrm{ppm}$. These analyses were carried out at Nuclear Materials Authority laboratories, Egypt.

3. Mineralogical identification have been done qualitatively by the $\mathrm{X}$ - ray diffraction (XRD) technique at laboratory of the NMA-Phillips XRD equipment (PW/3710), Cuk $\alpha$ - radiation (= $1.542 \mathrm{~A}^{\circ}$ )at $40 \mathrm{kv}, 30 \mathrm{~m} \mathrm{~A}$ and scanning speed $0.02 \%$ per sec. are used.

4. The ESEM-EDAX (Phillips Environmental Scanning Electron Microscope) model X130 with tungsten filament at NMA, Egypt were used for semi-quantitative elemental analysis and studying the texture within single grains.

5. Spectrometric study of all the rocks which are exposed at W. Zabara area by using (RS- 230) spectrometer.

\section{GEOLOGIC SETTING}

Zabara area is located at the northern part of south Eastern Desert of Egypt, The area is delineated by latitudes $24^{\circ} 43^{\prime} 30^{\prime \prime}$ and $24^{\circ} 46^{\prime} 30^{\prime \prime} \mathrm{N}$ and longitudes $34^{\circ} 39^{\prime} 00$ and $34^{\circ} 45^{\prime} 00 \mathrm{E}$ about $30 \mathrm{~km}$ southwest of Marsa Alam city on the red sea coast. Landsat 8 OLI data, for Zabara area were prepared (Fig. 1).

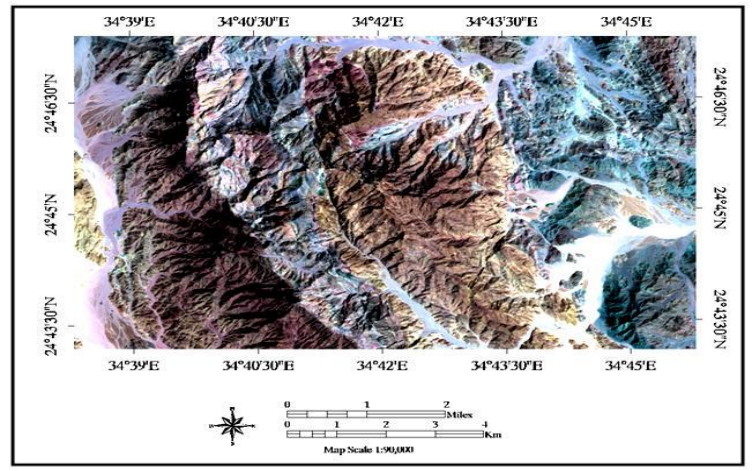

Fig 1. Landsat 8 OLI data, showing the location of Zabara area, SED, Egypt. 


\subsection{General Geology of Zabara Area}

The Zabara area is located at the northern part of the South Eastern Desert. The Neoproterozoic basement rocks cropping out in the Zabara area comprises; granite gneiss, serpentinite, mélange rocks and metavolcanic rocks (Fig. 2).

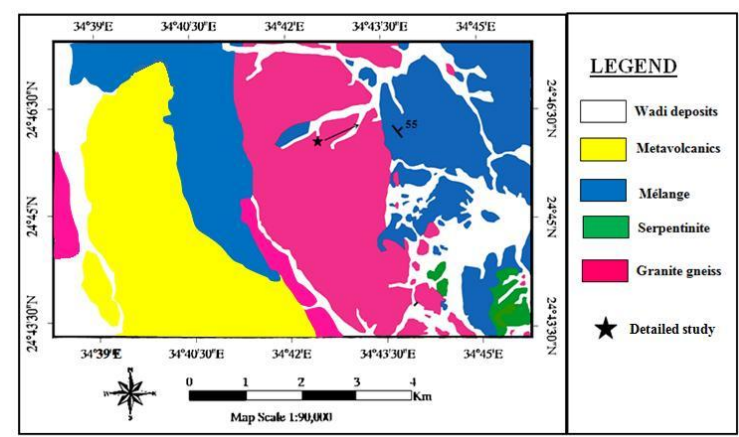

Fig 2. Geological map of the Zabara area, SED, Egypt (Modified after El-Bayoumi (1980), Conoco (1987), and Hassan (1998)\}.

The granite gneiss covering about $25 \mathrm{Km}^{2}$ from Zabara area.They comprise granite gneiss intercalated with bands or lenses of hornblende gneiss and minor migmatites, together with mylonites and schists (Kamel et al., 2016).

The Serpentinites are mottled, dark green and viscous rocks. The macro-structures of serpentinite bodies are often brecciated-boulder like fragments. The serpentinite bodies are almost sheared along the contacts with the other rocks varieties and completely altered to talc- tremolite carbonate rocks. They are tectonically overthrust the amphibolite, meta-sediments and meta-volcanics, show no signs of thermal metamorphism against the hostrocks suggesting that they are allochtonous and tectonically emplaced (El Sayed, 1997).

The ophiolitic mélange occupies the eastern and western parts of the study area and extends east and north beyond the mapped area.

The Metavolcanic rocks occur as thick layered and foliated sequence of grayish green to dark gray color. Island arc metavolcanics consist of meta-andesites, metadacites, tuff, with minor meta basalts and actinolite schist (Kamel et al., 2016).

\subsection{Detailed Geology of the Beryl Mines Area}

The geology of the beryl mines area has been studied by many authors (e.g.Hassan and El-Shatoury, 1976; Omar, 2001 and Takla et al. 2003).

Zabara beryl mines area is located at the north of the middle part of the mapped area (Fig.2). The length of Wadi Zabara is about $1.0 \mathrm{Km}$ while the width is about $250 \mathrm{~m}$ (Fig.3) and the berliferous zone extends along the contact between gneisses and schists. A huge mine dumps were observed in Zabara area formed during the old emerald mining and containing a significant amount of beryl (Fig.4). The main structural feature of this area as exposed in the detailed map (Fig. 3) is a plunging anticline in a N30 E direction (Hassan and El-Shatoury1976).

The rocks which are exposed in the Zabara beryl mines area are:

\section{Wadi deposits (Youngest)}

\section{Quartz veins}

\section{Schists}

\section{Gneisses (Oldest)}

These rock units can be explained in brief as following:

\subsection{Gneisses}

The gneisses are exposed at the eastern and western sides of $\mathrm{W}$. Zabara covering about $250 \mathrm{~m}^{2}$ with medium to high relief. They are medium to coarse grained and display pale pink to pale yellow color. 
The Geology, Geochemistry and Mineralogy of Beryl Mineralization in Zabara Area, South Eastern Desert, Egypt

These rocks are affected by weathering in variable degrees giving their colors due to the alteration process and producing iron oxides (Fig.5). Vertical fractures and joints are occurred in the gneisses dominantly in N-S trends. Some of these fractures are filled by quartz veins. The contact between the gneisses and over thrusting schists is usually sharp contact (Fig.6), although sometimes it shows gradational contact.

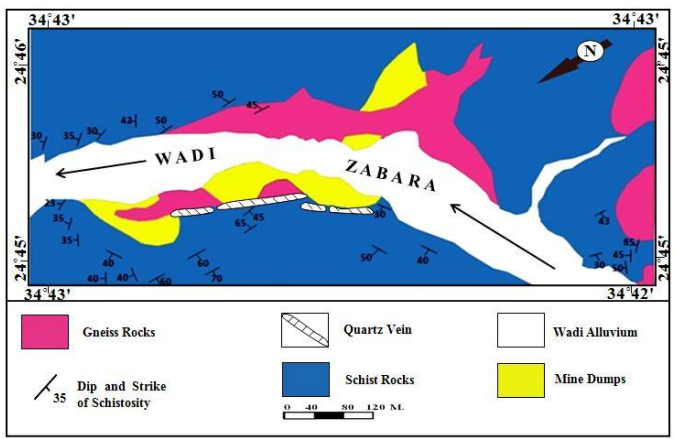

Fig 3. Detailed Geologic map of Zabara area, south Eastern Desert, Egypt (Modified after Hassan and ElShatoury., 1976).

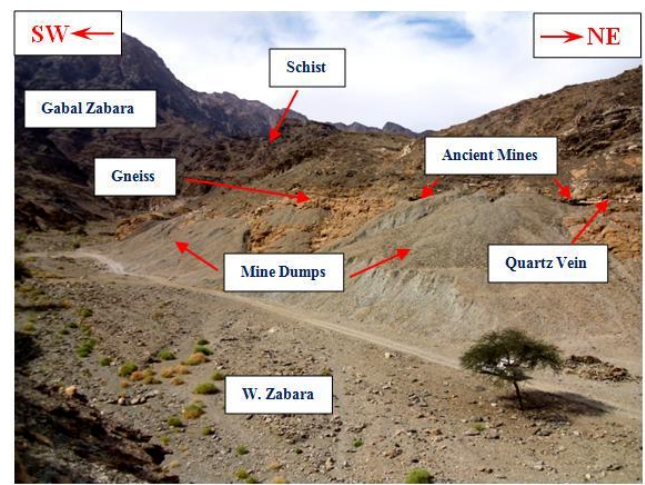

Fig 4. A photo showing mine dumps and old mining exposed at W. Zabara area, SED, Egypt.

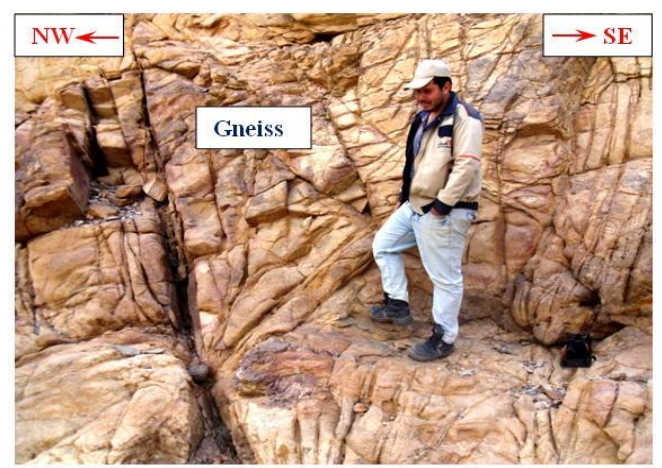

Fig 5. A photo showing vertical fractures and oxidation processes forming iron oxides in the gneiss at W. Zabara area, SED, Egypt.

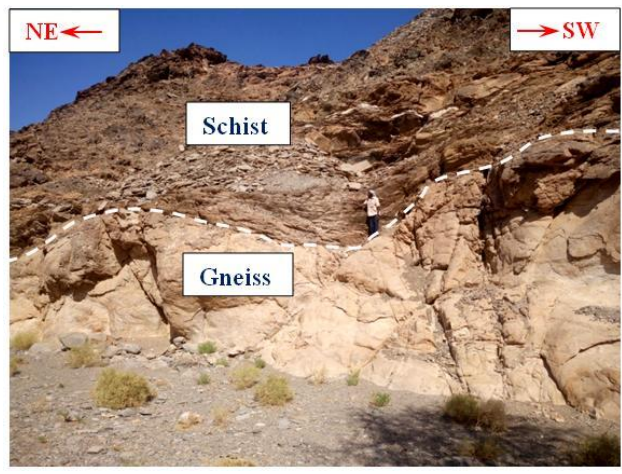

Fig 6. A photo showing sharp contact between the gneiss and overlying schist at W. Zabara area, SED, Egypt. 
The Geology, Geochemistry and Mineralogy of Beryl Mineralization in Zabara Area, South Eastern Desert, Egypt

\subsection{Schists}

They represent the most predominant rock unite within Zabara beryl mines area, covering about 1.0 $\mathrm{Km}^{2}$. It is composed mainly of differentvarieties of schists such as hornblende schist, quartzofeldspathic schist and garnet biotite schist (Fig.7) that found in many places in this area. These rocks show medium relief, high deformation and schistosty structure. In some of these schists (phlogopite schist) beryl crystals aredisseminated into this type. The beryl mineralization is restricted to the contact between these rocks and gneiss rocks. The beryl crystals show small grained size and pale green color (Fig.8).

The schist rocks are characterized by NW-SE foliation with dip angle ranges from $30^{\circ}-70^{\circ}$ and by boudinaged quartz extending parallel to the foliation planes. They are highly folded and wrinkled strata due to the tectonic deformation (Fig.9). Also they have thrust contacts against the underlying gneiss rocks showing sharp contacts between them in both sides of W. Zabara; this thrust contact trends NNW direction and dips $38^{\circ}$ toward NE (Fig.10). These schists intruded by a number of quartz veins (Fig.11).

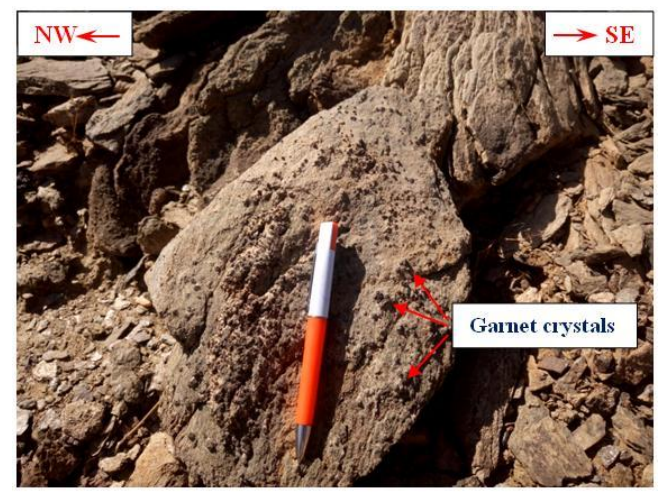

Fig 7. A photo showing garnet crystals in garnetiferous biotite schist at W. Zabara area, SED, Egypt.

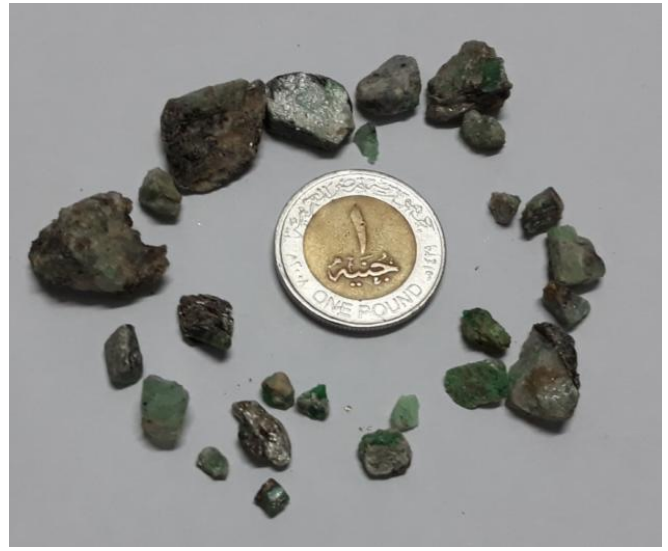

Fig 8. Some of beryl grains associating with phlogopite schist from the mine dumps at W. Zabara area, SED, Egypt.

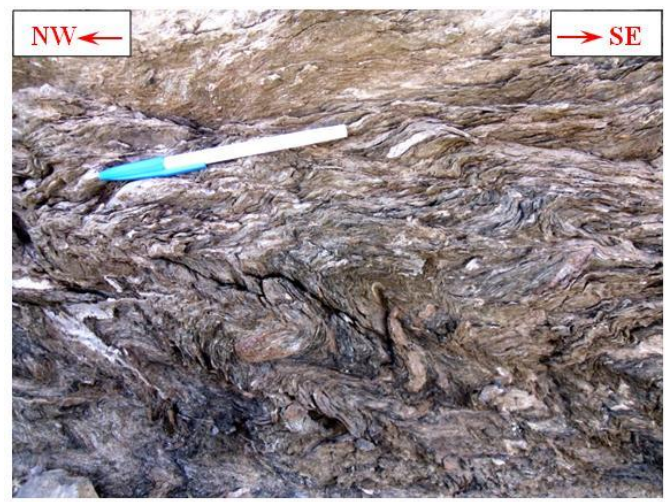

Fig 9. A photo showing chevron folding process in biotite schist at W. Zabara area, SED, Egypt. 
The Geology, Geochemistry and Mineralogy of Beryl Mineralization in Zabara Area, South Eastern Desert, Egypt

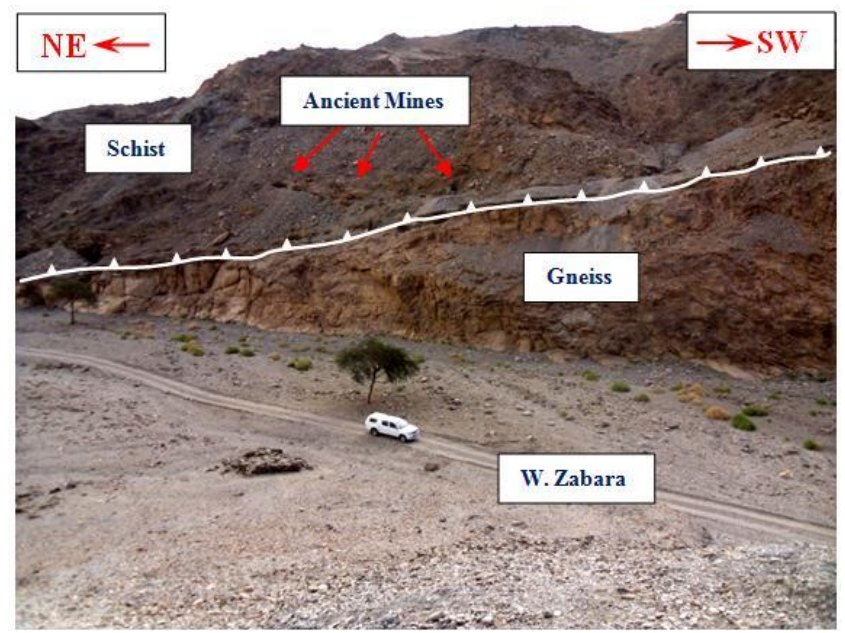

Fig 10. A photo showing schist rocks thrusted over gneiss rocks at W. Zabara area, SED, Egypt.

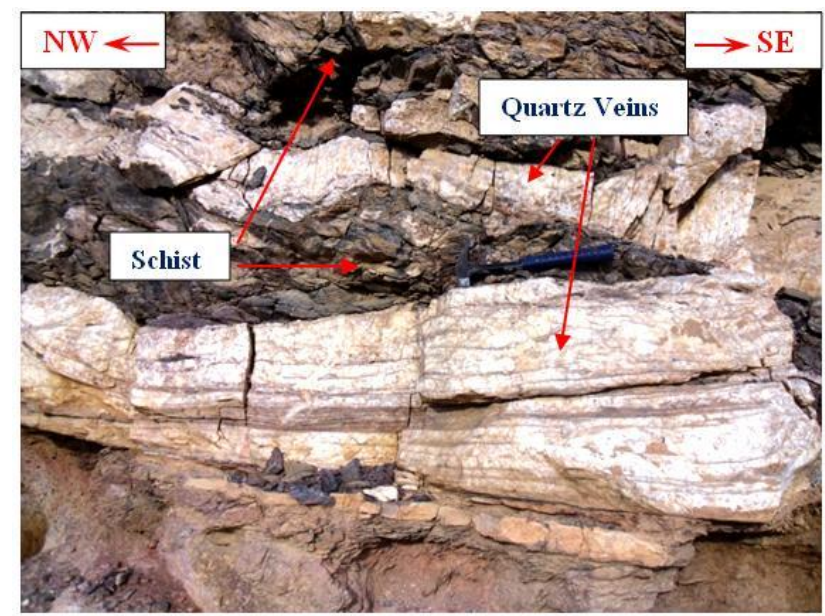

Fig 11. A photo showing quartz veins cut in the schist rocks at W. Zabara area, SED, Egypt.

\subsection{Quartz Veins}

W. Zabara beryl mines area is dissected by number of quartz veins, some of them are mineralized with beryl (Fig.12); others are barren (Fig.13). These quartz veins including beryl mineralizations have length about $300 \mathrm{~m}$, thickness about $3 \mathrm{~m}$ and width reaches up to $4 \mathrm{~m}$ (Fig. 14), they have NE-SW direction and dipping toward NW. The beryl crystals characterized by small grain size, fractured and pale green in color (Fig.12).

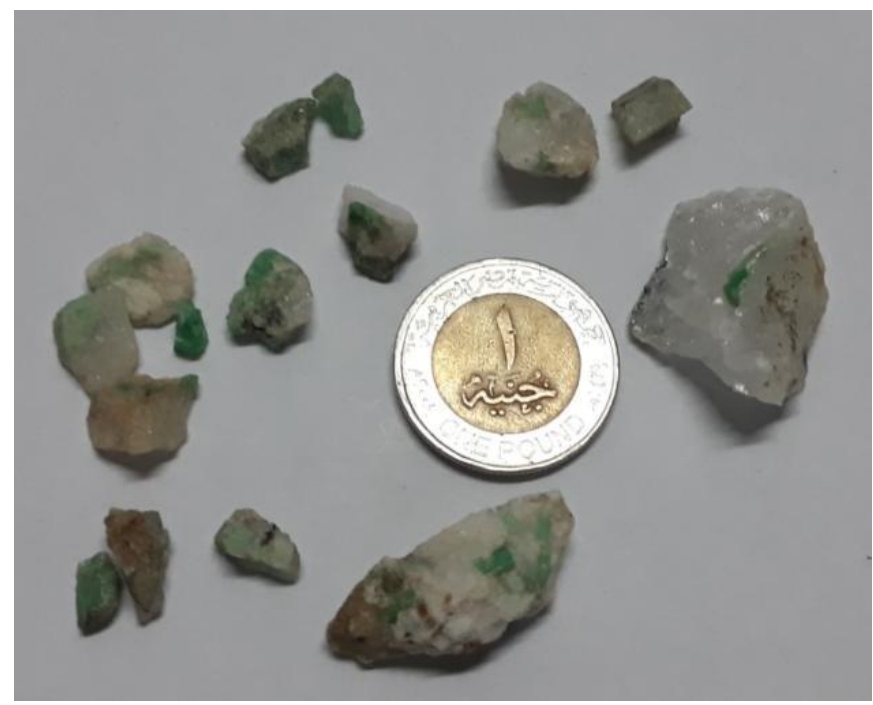

Fig 12. Some of beryl grains from quartz veins at W. Zabara area, SED, Egypt. 
The Geology, Geochemistry and Mineralogy of Beryl Mineralization in Zabara Area, South Eastern Desert, Egypt

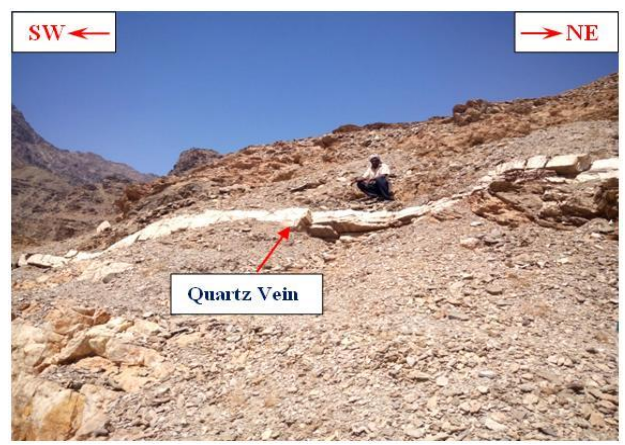

Fig 13. A photo showing the barren quartz vein cutting schist rocks at W. Zabara area, SED, Egypt.

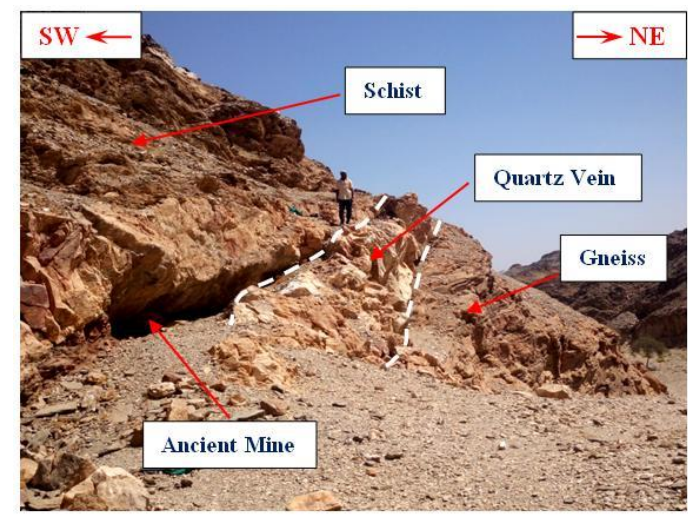

Fig 14. A photo showing the beryl-bearing quartz vein cutting the schist and gneiss at W. Zabara area, SED, Egypt.

Ancient mines working occurs in considerable amount in this area especially at the schists-gneisses contact (Fig.15). Also the ancient mines occurred either at the contact between the quartz veins and gneisses or schists (Figs.16\&17). At Zabara area the old buildings for workers were constructed by various types of schist (Fig. 18).

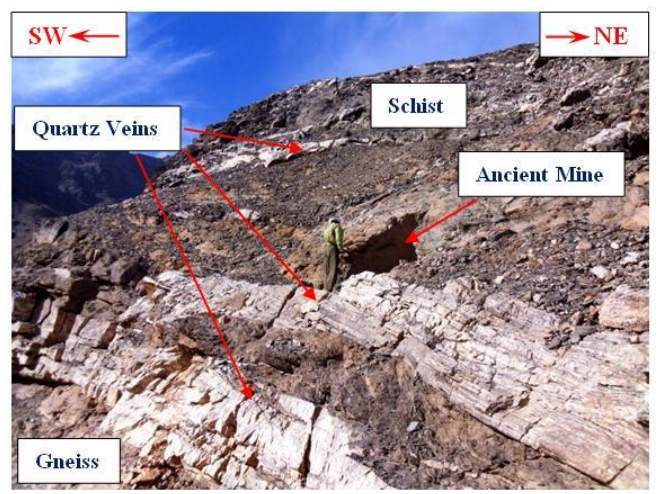

Fig 15. A photo showing the small ancient tunnel between the gneiss and schist at W. Zabara area, SED, Egypt.

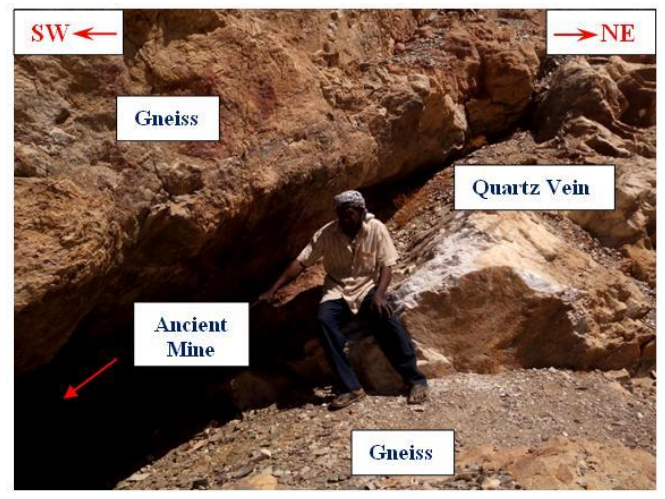

Fig 16. A photo showing big ancient tunnel between the gneiss rocks andquartz vein at W. Zabara area, SED, Egypt. 
The Geology, Geochemistry and Mineralogy of Beryl Mineralization in Zabara Area, South Eastern Desert, Egypt

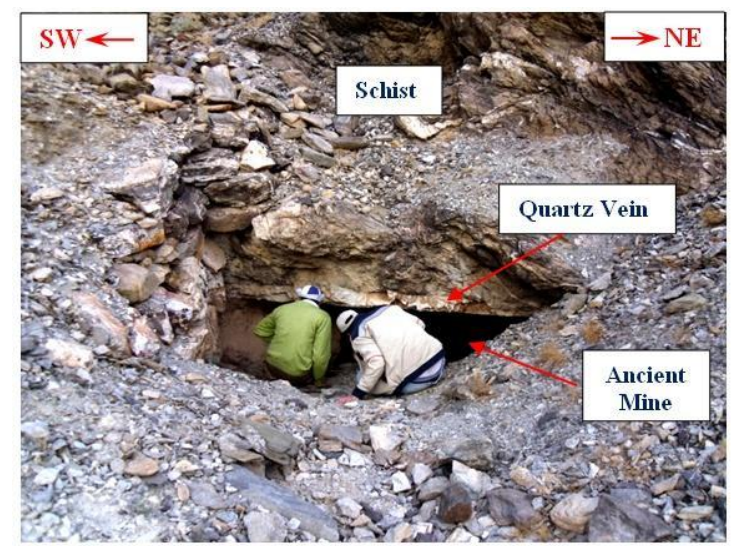

Fig 17. A photo showing the ancient tunnel between the schist and quartz vein at W. Zabara area, SED, Egypt.

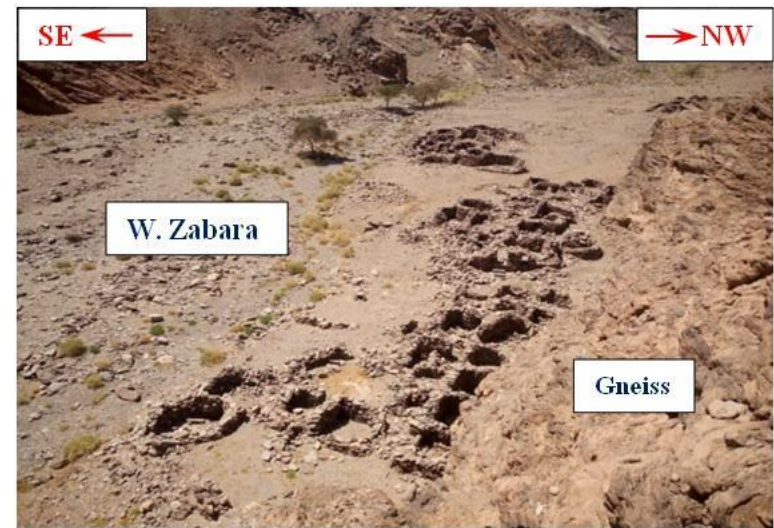

Fig 18. A photo showing the ancient worker buildings at Zabara area, SED, Egypt.

\subsection{Wadi Deposits}

The Wadi deposits at Zabara area have various types of rocks such as schist rocks and gneiss rocks, as well as the fragments of quartz. Some of Beryl fractions also exist in these sediments.

\section{Petrography}

Quartz veins and phlogopite schist are the main rocks varieties that bearing beryl mineralization in W. Zabara area.

\subsection{Beryl In Quartz-Veins}

Quartz-veins in Zabara area composed mainly of quartz that fractured in part. The accessory minerals are iron oxides and beryl. Quartz present as coarse grained and highly deformed. Beryl occurred as a small prismatic crystal associating the quartz (Fig.19a). Beryl crystals characterized by high relief with green color (Fig.19b). Beryl characterized by cracking, parting and corroded by quartz (Fig. 19a).

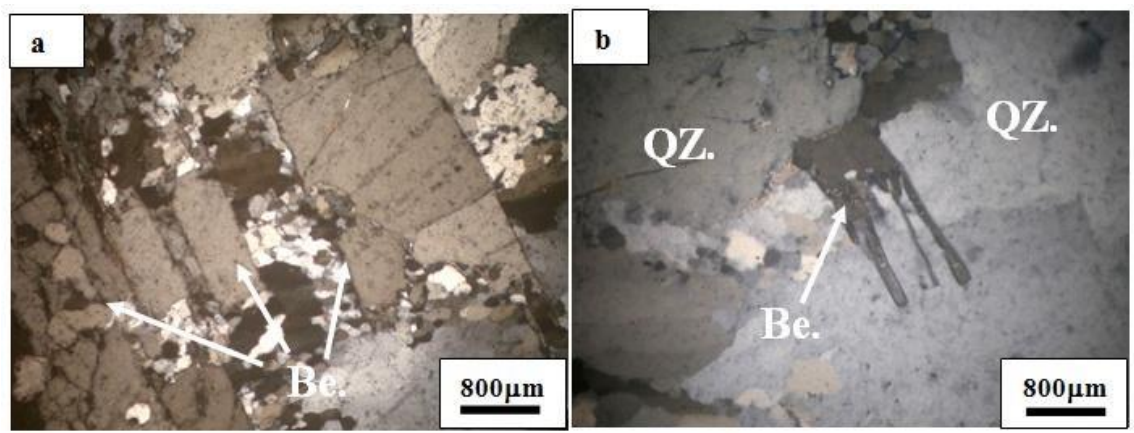

Fig 19. Photomicrographs of beryl in quartz vein of Zabara occurrence, SED, Egypt, showing: a) Three fractured crystals of beryl (Be.) associating with quartz, CN. and b) Beryl crystal shown high relief associating with quartz, $C N$. 
The Geology, Geochemistry and Mineralogy of Beryl Mineralization in Zabara Area, South Eastern Desert, Egypt

\subsection{Beryl in phlogopite schist}

The phlogopite occurred as flakes at the boundaries of quartz veins. Muscovite occurs as small closed veinlets (Fig.20). Beryl crystals occurred at the contact between quartz and these schists.

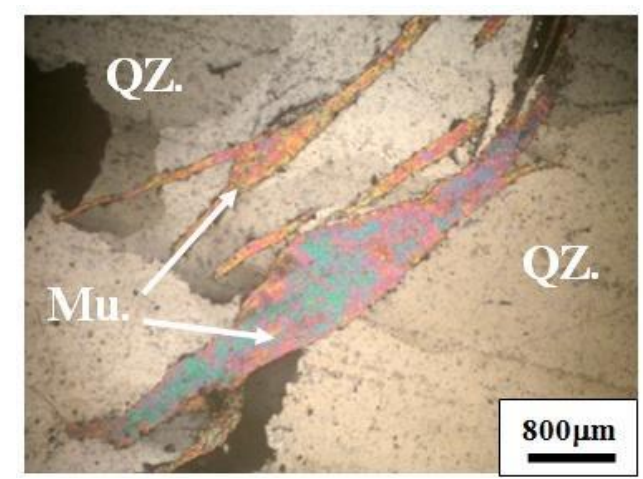

Fig 20. Photomicrographs of phlogopite schist that hosting beryl at the contact of quartz, CN.

\section{Mineralogy}

The main beryl-bearing rocks in Zabara area are; quartz veins and phlogopite schists.

\subsection{Quartz Veins-Hosted Beryl}

The quartz veins hosted beryl mineralization in Zabara area appeared as large sized veins. These veins intruded in schist rocks and have NE-SW direction. The beryl shows small size (less than $1 \mathrm{~cm}$ ) and impure crystals with pale green color (Fig.21).

The XRD pattern of these beryl crystals (Fig.22) shows their peaks at d-values (7.95, 4.58, 3.98 and $2.87 \AA ̊$ ) matching with ASTM card No. (0078-2232). In addition to the beryl peaks, minor peaks of quartz are also identified. The SEM analysis of beryl detects thatthe $\mathrm{Si}, \mathrm{Al}, \mathrm{Mg}$ and Naas the major constituent beside Fe, Ti, Ca and K (Fig.23).

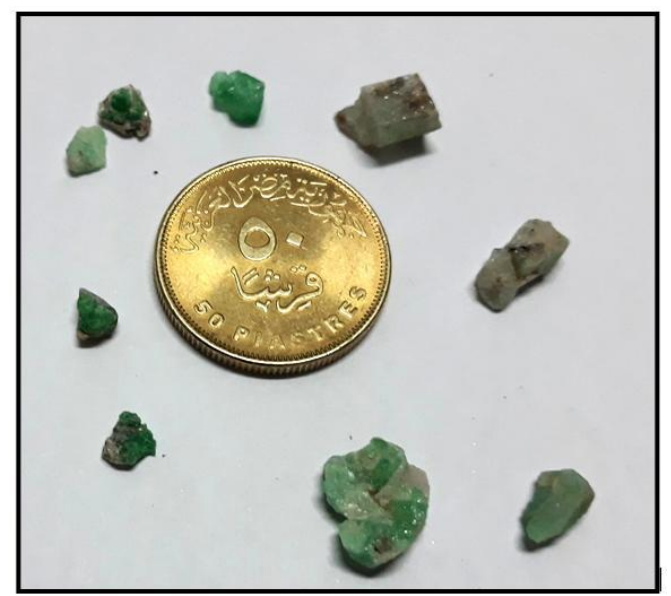

Fig 21. Beryl crystals separated from quartz veins at Zabara area, SED, Egypt.

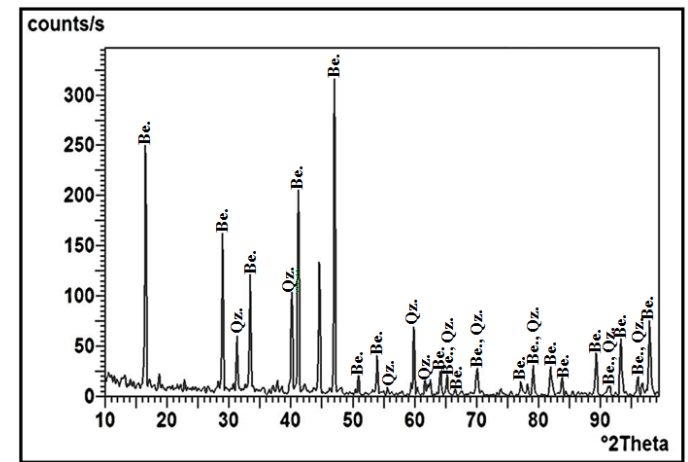

Fig 22. X-ray diffraction pattern of beryl mineral (Be) hosted in quartz at Zabara area, SED, Egypt. 
The Geology, Geochemistry and Mineralogy of Beryl Mineralization in Zabara Area, South Eastern Desert, Egypt

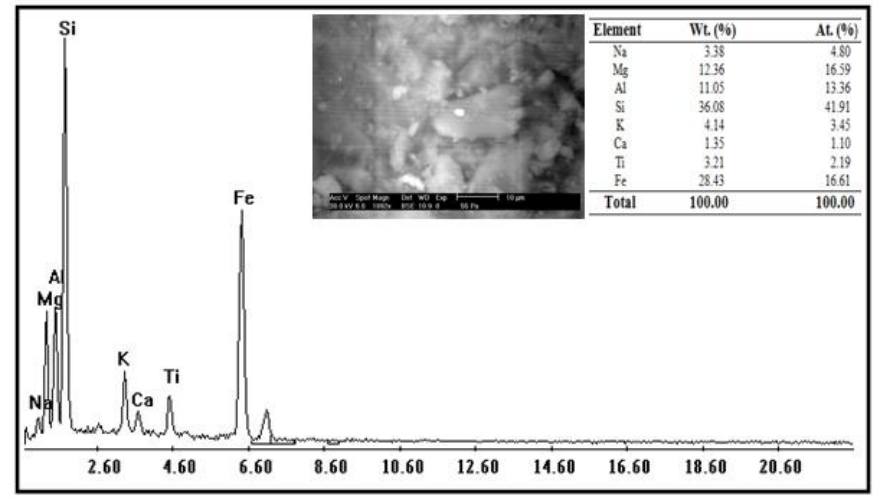

Fig 23. Back-scattered electron-SEM image and EDAX analysis of beryl crystal hosted in quartz veins at Zabara area, SED, Egypt.

\subsection{Phlogopite Schist-Hosted Beryl}

The phlogopite schist is the most common beryl-bearing rocks in Zabara area. These rocks have been intruded by a number of quartz veins. Beryl occurs as a small grain sized (less than $1 \mathrm{~cm}$ ) with green color (Fig.24).

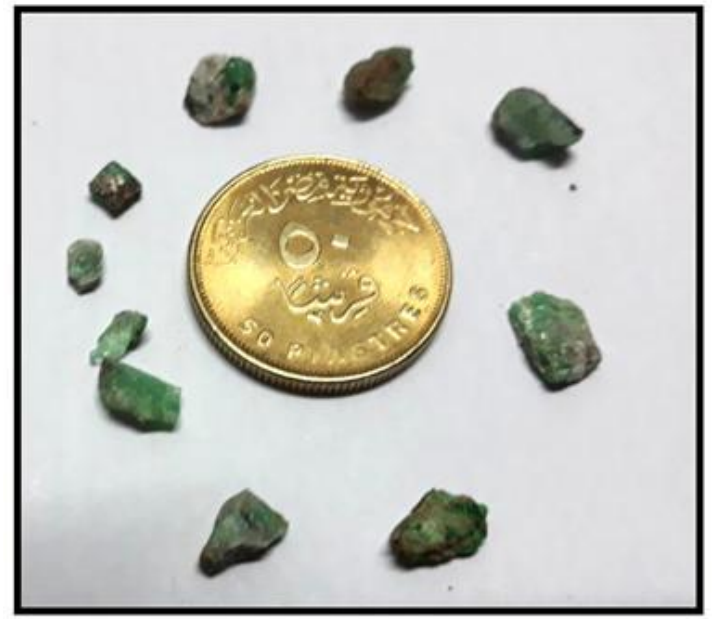

Fig 24. Beryl crystals separated from phlogopite schist at Zabara area, SED, Egypt.

These beryl crystals were investigated by XRD (Fig.25) with characteristic d-values (8.01, 4.60, 3.02 and 2.88 $\AA$ ) matching with ASTM card No. (0047-1826). Peaks of muscovite are also identified. However, The SEM (EDAX) analysis of these beryl crystals shows that the $\mathrm{Si}, \mathrm{Al}, \mathrm{Mg}$ and $\mathrm{Na}$ are the main constituents besideFe, $\mathrm{Ca}$, Ni and K (Fig.26).

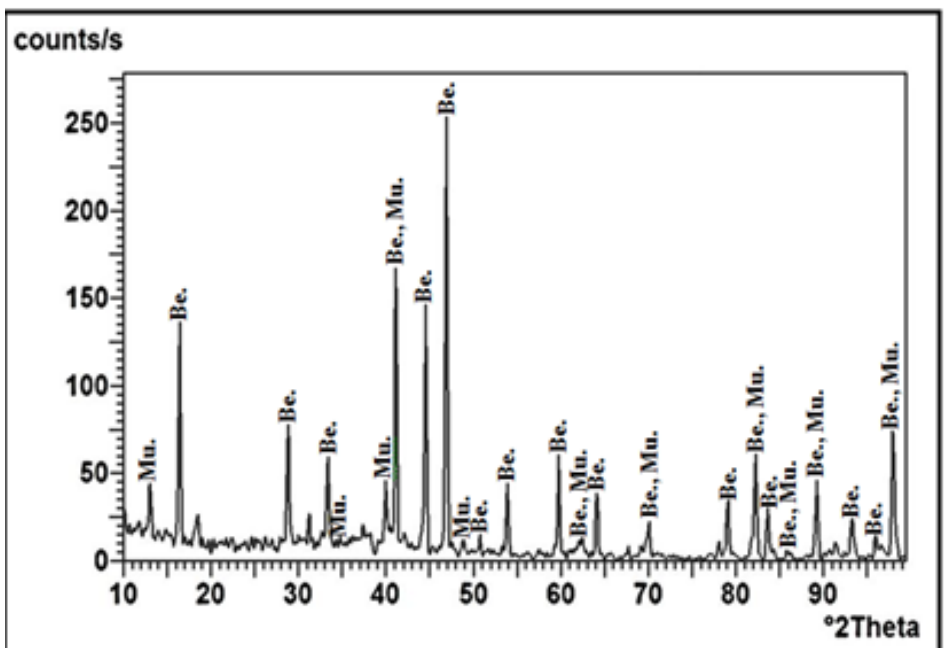

Fig 25. X-ray diffraction pattern of beryl mineral (Be) hosted in phlogopite schist in Zabara area, SED, Egypt. 


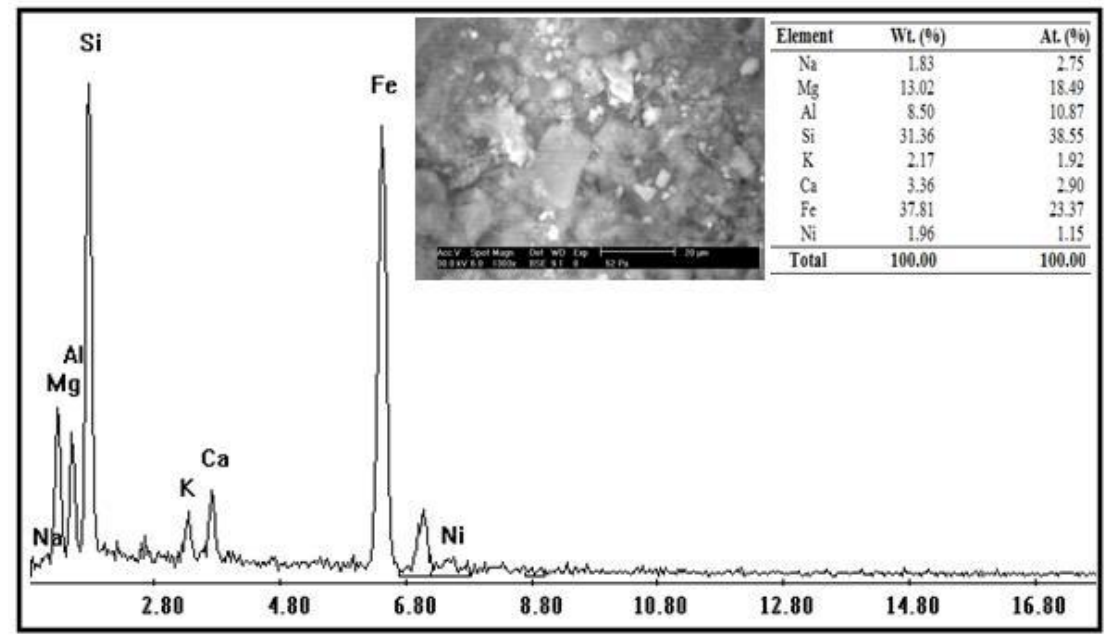

Fig 26. Back-scattered electron-SEM image and EDAX analysis of beryl crystal hosted in phlogopite schist in Zabara area, SED, Egypt.

The XRD analysis of beryl in Zabara area displayed beryl and quartz peaks, in case of quartz-hosted beryl, suggesting that the beryl crystals were fractured and filled by quartz. In case of phlogopite schist-hosted beryl, it displayed beryl and muscovite peaks in X-ray diffractogram suggesting that the beryl crystals were fractured and filled by schist.

The SEM(EDAX) analysis of berylin Zabara area shows that the $\mathrm{Si}, \mathrm{Al}, \mathrm{Mg}$ and $\mathrm{Na}$ are the main constituents beside $\mathrm{Fe}, \mathrm{Ca}$ and $\mathrm{K}$. Ti appeared in quartz-hosted beryl, whereas $\mathrm{Ni}$ appeared in phlogopite schist-hosted beryl.

\section{SPECTROMETRY}

The main rocks which are exposed in the studied area are schists and gneisses with abundantquartz veins.

The spectrometric survey of these rocks showsthat the radioactivity is related tothe gneisses. The spectrometric data statisticsof these rocks are summarized in table (1).

Table1. Statistics of spectrometric data and their ratios of the exposed rocks in Zabara area, SED, Egypt.

\begin{tabular}{|c|c|c|c|c|c|c|c|c|c|c|c|c|c|c|}
\hline \multirow{2}{*}{$\begin{array}{l}\text { Rock } \\
\text { type }\end{array}$} & \multicolumn{4}{|c|}{$K \%$} & \multicolumn{4}{|c|}{$e U(p p m)$} & \multicolumn{4}{|c|}{ eTh (ppm) } & \multicolumn{2}{|c|}{ Ratios } \\
\hline & $\mathbf{N}$ & $\begin{array}{c}\text { Mi } \\
\text { n. }\end{array}$ & $\begin{array}{c}\text { Max } \\
. \\
\end{array}$ & $\mathbf{X}$ & $\mathbf{N}$ & $\begin{array}{c}\text { Mi } \\
\text { n. }\end{array}$ & Max. & $\mathbf{X}$ & $\mathbf{N}$ & $\begin{array}{c}\text { Min } \\
.\end{array}$ & Max. & $\mathbf{X}$ & $\begin{array}{c}e U / e \\
T h \\
\end{array}$ & $\begin{array}{c}\boldsymbol{e T h} / \boldsymbol{e} \\
U\end{array}$ \\
\hline $\begin{array}{c}\text { Schis } \\
\mathbf{t} \\
\end{array}$ & 15 & 0.3 & 3.5 & 1.8 & 4 & 1.5 & 2.3 & 1.8 & 4 & 0.7 & 7 & 3.05 & 1.01 & 1.5 \\
\hline $\begin{array}{c}\text { Gnei } \\
\text { SS } \\
\end{array}$ & 54 & 1 & 7.8 & $\begin{array}{c}3.8 \\
9\end{array}$ & 54 & 5 & 18 & $\begin{array}{l}10 . \\
05\end{array}$ & 54 & 10 & 85 & $\begin{array}{c}33.4 \\
7\end{array}$ & 0.32 & 3.60 \\
\hline \multicolumn{15}{|c|}{ Crustal acidic igneous rocks (after IAEA, 1979) } \\
\hline & & - & - & 4 & - & - & - & 4.5 & - & - & - & 18 & 0.25 & - \\
\hline \multicolumn{15}{|c|}{ (Clarke et.al, 1966) } \\
\hline & & - & - & - & & - & - & 4 & - & - & - & 19 & 0.25 & - \\
\hline
\end{tabular}

\section{N: number of measurements Min.: MinimumMax.: Maximum X: Mean}

From table (1), it is cleared that the gneiss rocks have K\% contents $(3.89 \%)$ higher than the schist rocks $(1.8 \%)$. The gneiss rocks have $\mathrm{eU}$ and eTh contents as (10.05 \& 33.47) respectively; these values are higher than those of schists $(1,8 \& 3.05)$ respectively. The average of eU/eTh ratio for gneisses (0.32) is lower than the average value of eU/eTh ratio for schists (1.01) (Fig.27a).

The relation of the radioelements concentration in the gneiss rocks to those of the crustal igneous rocks after IAEA (1979) and Clarke et al., (1966) is listed in table (1) and shows that; the average value of $K \%$ of the gneiss rocksis lesser than those the corresponding crustal average values, but the average values of $e U$ and $e T h$ is higher than those the corresponding crustal average value.The average 
The Geology, Geochemistry and Mineralogy of Beryl Mineralization in Zabara Area, South Eastern Desert, Egypt

value and range of eU/eTh ratio of the gneiss rocks are higher than those the corresponding crustal average value.

From the above correlation (Table1), the gneiss rocks at Zabara area are relatively abnormal case as the corresponding crustal average values. These rocks have high values of radioactive elements.

The binary correlation diagrams constrain the behavior of the investigated radioactive elements and their distribution in the studied gneiss rocks (Fig.27).The correlation between eU and eTh indicates a weakly positive correlation $(\mathrm{r}=0.16)$ suggesting that their distribution was controlled by the magmatic processes (Stuckless et. al., 1983) (Fig.27b). The correlation between eU and eU/eTh (Fig.27c) shows a medium positive correlation $(\mathrm{r}=0.42)$ suggesting that the post magmatic redistribution of $\mathrm{U}$, while the correlation between eTh and eU/eTh displays strongly negative correlation $(r=-0.68)$ this indicate the redistribution of $U$ mineralization and Th was fixed in these rocks (Mahmoud, 2009; Fig.27d).

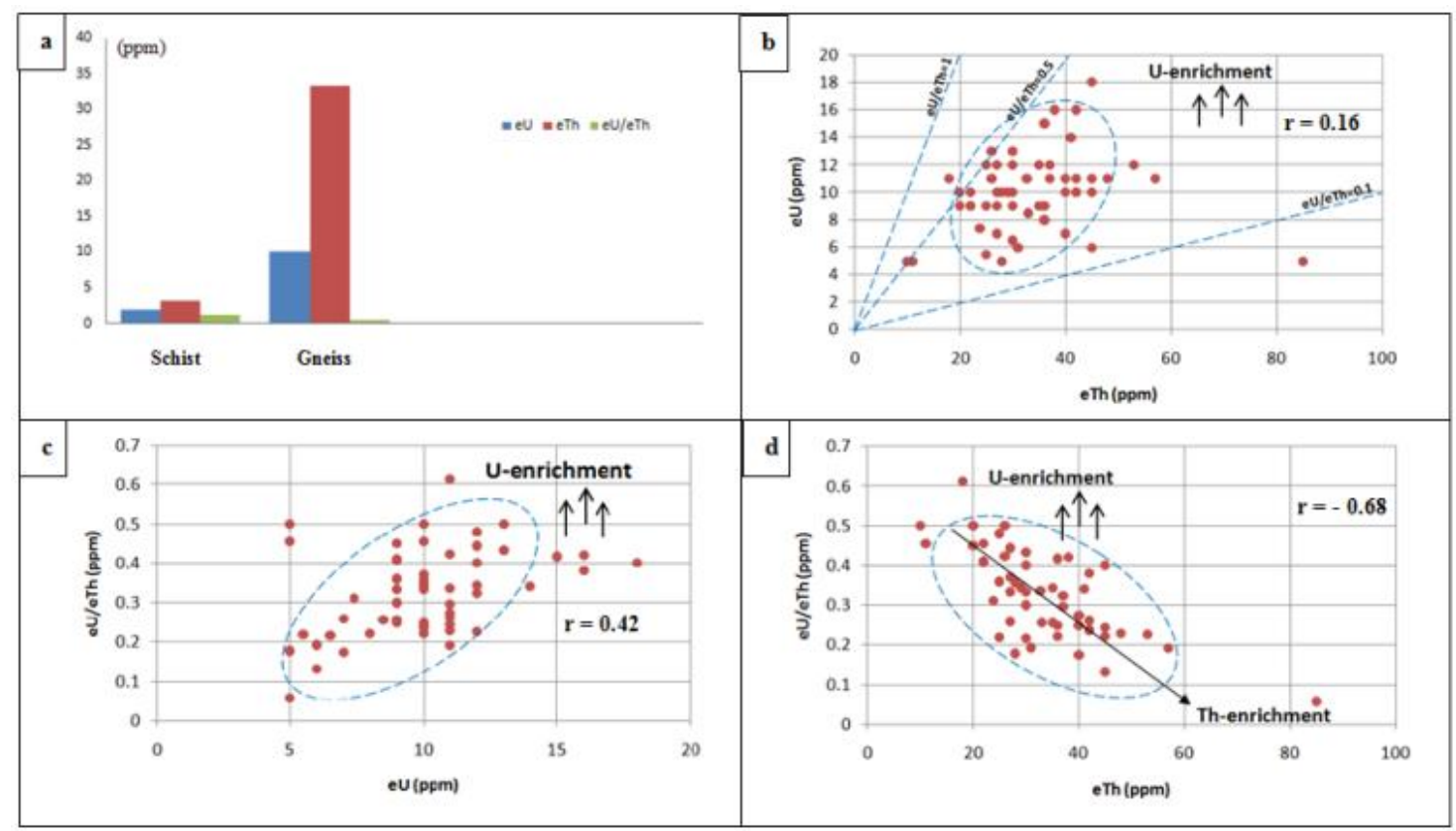

Fig 27. Radioactive elements plots at Zabara area, SED, Egypt. showing:-a) Bar- diagram showing the average of eU(ppm), eTh(ppm) and ratio of eU/eTh of schist and gneisses, b) Binary correlation diagram between eU vs. eTh, c) Binary correlation diagram between eU/eTh vs. eU and d) Binary correlation diagram between eU/eTh

\section{GEOCHEMISTRY}

\subsection{Geochemistry of Gneisses}

Five samples from the gneisses of Zabara area were subjected to chemical analysis. The major oxides, trace elements and calculated CIPW normative values of these samples are listed in table (2). The average values of the major oxides in the studied gneiss rocks were calculated to compare them with similar average values of the gneiss rocks of Abu Rusheid area (Saleh, 1997). The analyses and their averages are listed in table (3).

Table2. Major oxides, CIPW values and trace elements values of the studied gneisses at Zabara area, SED, Egypt.

\begin{tabular}{|c|c|c|c|c|c|c|}
\hline $\begin{array}{l}\text { Major } \\
\text { Oxides }\end{array}$ & \multicolumn{7}{|c|}{ Zabara area (Gneisses) } \\
\hline \multicolumn{7}{|c|}{ Major Oxides (Wt. \%) } \\
\hline $\mathrm{S}$. No. & 1 & 2 & 3 & 4 & 5 & Ave. \\
\hline $\mathrm{SiO}_{2}$ & 73.7 & 75 & 74.4 & 72.3 & 73.4 & 73.76 \\
\hline $\mathrm{Al}_{2} \mathrm{O}_{3}$ & 12.3 & 11.5 & 11.9 & 13.4 & 12.4 & 12.3 \\
\hline $\mathrm{TiO}_{2}$ & $\mathbf{0 . 0 7}$ & 0.01 & 0.03 & 0.02 & 0.03 & 0.032 \\
\hline $\mathrm{Fe}_{2} \mathrm{O}_{3}$ & 1.8 & 2.57 & 2.2 & 2.89 & 2.42 & 2.376 \\
\hline $\mathrm{CaO}$ & 1.12 & 0.86 & 1 & 0.77 & 0.91 & 0.932 \\
\hline
\end{tabular}


The Geology, Geochemistry and Mineralogy of Beryl Mineralization in Zabara Area, South Eastern Desert, Egypt

\begin{tabular}{|c|c|c|c|c|c|c|}
\hline MgO & 0.5 & 0.3 & 0.5 & 0.6 & 0.4 & 0.46 \\
\hline $\mathrm{Na}_{2} \mathrm{O}$ & 4.8 & 3.65 & 4.3 & 4.3 & 4.25 & 4.26 \\
\hline $\mathrm{K}_{2} \mathrm{O}$ & 2.85 & 2.55 & 2.4 & 3.82 & 3.07 & 2.938 \\
\hline $\mathbf{P}_{2} \mathbf{O}_{5}$ & 1.49 & 2.83 & 2.16 & 1.07 & 1.79 & 1.868 \\
\hline MnO & 0.03 & 0.02 & 0.03 & 0.04 & 0.03 & $\mathbf{0 . 0 3}$ \\
\hline LOI & 1.21 & $\mathbf{0 . 3 8}$ & 0.8 & 0.54 & 0.71 & $\mathbf{0 . 7 2 8}$ \\
\hline Total & 99.87 & 99.67 & 99.79 & 99.75 & 99.73 & 99.762 \\
\hline \multicolumn{7}{|c|}{ CIPW normative values } \\
\hline $\mathbf{Q}$ & 34.13 & 43.57 & 38.9 & 31.78 & 36.48 & 36.972 \\
\hline C & 1.31 & 2.73 & 2 & 2.19 & 2.07 & 2.06 \\
\hline Or & 16.84 & 15.07 & 15.6 & 22.57 & 18.16 & 17.648 \\
\hline $\mathbf{A b}$ & 40.61 & 30.88 & 35.8 & 36.38 & 35.95 & 35.924 \\
\hline Hy & 1.24 & 0.74 & 0.97 & 1.49 & 1.15 & 1.118 \\
\hline Mt & 0.09 & 0.06 & 0.07 & 0.13 & 0.09 & $\mathbf{0 . 0 8 8}$ \\
\hline Hm & 1.73 & 2.52 & 2.13 & 2.8 & 2.35 & 2.306 \\
\hline SUM & 95.98 & 95.59 & 95.47 & 97.35 & 96.30 & 96.138 \\
\hline \multicolumn{7}{|c|}{ Trace elements (ppm) } \\
\hline $\mathbf{C r}$ & 54 & 29 & 41 & 34 & 39 & 39.4 \\
\hline $\mathbf{C u}$ & 40 & 49 & 44 & 44 & 44 & 44.2 \\
\hline $\mathbf{N i}$ & 4 & 5 & 4 & 6 & 5 & 4.8 \\
\hline $\mathbf{Z n}$ & 26 & 58 & 45 & 33 & 39 & 40.2 \\
\hline $\mathbf{Z r}$ & 36 & 95 & 68 & 149 & 93 & 88.2 \\
\hline Ga & 13 & 8 & 11 & 41 & 20 & 18.6 \\
\hline $\mathrm{Sr}$ & 49 & 147 & 100 & 247 & 147 & 138 \\
\hline $\mathbf{Y}$ & 32 & 42 & 39 & 41 & 38 & 38.4 \\
\hline $\mathbf{R b}$ & 271 & 271 & 277 & 292 & 278 & 277.8 \\
\hline $\mathbf{V}$ & 3 & 3 & 4 & 2 & 3 & 3 \\
\hline $\mathrm{Nb}$ & 2 & 4 & 5 & 7 & 4 & 4.4 \\
\hline $\mathbf{P b}$ & 37 & 28 & 33 & 24 & 29 & 30.2 \\
\hline Ba & 110 & 105 & 100 & 84 & 101 & 100 \\
\hline
\end{tabular}

Table3. The averages of the major oxides of the studied gneisses compared with averages of the major oxides of gneiss at Abu Rusheid area, SED, Egypt.

\begin{tabular}{|c|c|c|}
\hline S. No. & 1 & 2 \\
\hline $\mathrm{SiO}_{2}$ & 73.76 & 75.78 \\
\hline $\mathrm{Al}_{2} \mathrm{O}_{3}$ & 12.3 & 10.75 \\
\hline $\mathrm{TiO}_{2}$ & 0.032 & 0.68 \\
\hline $\mathrm{Fe}_{2} \mathrm{O}_{3}{ }^{\mathrm{t}}$ & 2.376 & - \\
\hline $\mathrm{Fe}_{2} \mathrm{O}_{3}$ & - & 2.17 \\
\hline $\mathrm{FeO}$ & - & 1.43 \\
\hline $\mathrm{CaO}$ & 0.932 & 0.91 \\
\hline $\mathrm{MgO}$ & 0.46 & 0.37 \\
\hline $\mathrm{Na}_{2} \mathrm{O}$ & 4.26 & 3.93 \\
\hline $\mathrm{K}_{2} \mathrm{O}$ & 2.938 & 3.27 \\
\hline $\mathbf{P}_{2} \mathbf{O}_{5}$ & 1.868 & 0.08 \\
\hline MnO & 0.03 & 0.08 \\
\hline LOI & $\mathbf{0 . 7 2 8}$ & $\mathbf{0 . 8 2}$ \\
\hline Total & 99.762 & 100.27 \\
\hline
\end{tabular}

1- Average of the studied gneisses (Zabara area), SED, Egypt.

2- Average of the gneisses of Abu Rusheid area (Saleh, 1997).

From (Table 3) it is cleared that; the studied gneiss rocks have higher values of $\mathrm{Al}_{2} \mathrm{O}_{3}, \mathrm{MgO}, \mathrm{Na}_{2} \mathrm{O}$ and $\mathrm{P}_{2} \mathrm{O}_{5}$ than those in Abu Rusheid area (Fig.28). On the other hand, Abu Rusheid gneiss rocks - the 
The Geology, Geochemistry and Mineralogy of Beryl Mineralization in Zabara Area, South Eastern Desert, Egypt

highest radioactive anomaly in Egypt - have higher values of $\mathrm{SiO}_{2}, \mathrm{TiO}_{2}, \mathrm{~K}_{2} \mathrm{O}$ and $\mathrm{MnO}$ than those in Zabara area.

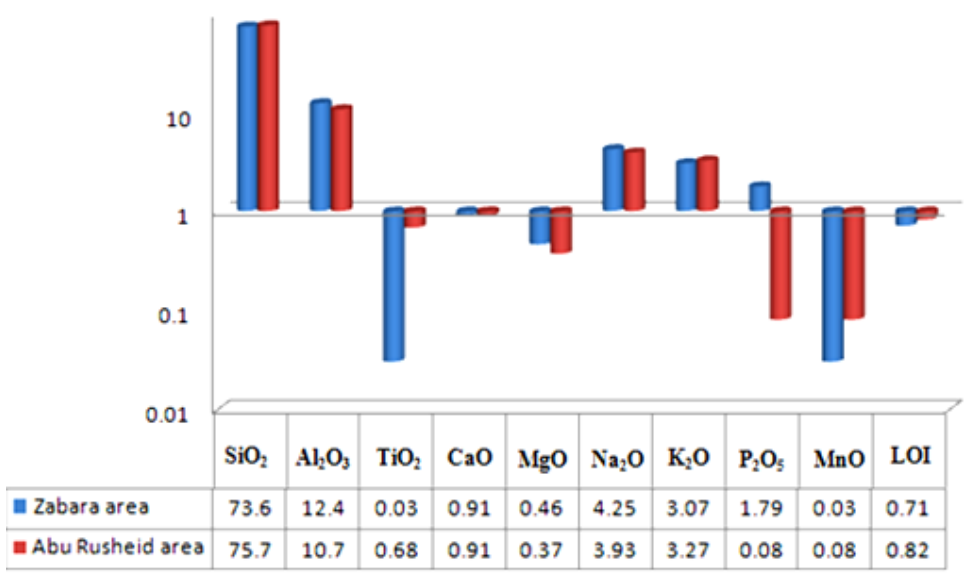

Fig 28. Bar-diagram showing the average of major oxides of gneiss rocks at Zabara and Abu Rusheid areas, SED, Egypt.

\subsection{Geochemistry of Schists}

Five samples from the schist rocks of Zabara area were subjected to chemical analysis. The major oxides, trace elements and calculated CIPW normative values of these samples are listed in table (4).The average values of the major oxides in the studied schist rocks were calculated to compare them with similar average values of the schist rocks of Wadi El Gemal (Omar,2001). The analyses and their averages are listed in table (5).

Table4. Major oxides, CIPW values and trace elements values of the studied schist rocks at Zabara area, SED, Egypt.

\begin{tabular}{|c|c|c|c|c|c|c|}
\hline \multicolumn{7}{|c|}{ Zabara area (Schist) } \\
\hline \multicolumn{7}{|c|}{ Major Oxides (Wt. \%) } \\
\hline S. No. & 1 & 2 & 3 & 4 & 5 & Ave. \\
\hline $\mathrm{SiO}_{2}$ & 69.2 & 68.7 & 68.4 & 68.9 & 68.7 & 68.78 \\
\hline $\mathbf{A l}_{2} \mathbf{O}_{3}$ & 15.3 & 13.8 & 14.8 & 14.5 & 14.6 & 14.6 \\
\hline $\mathrm{TiO}_{2}$ & 1.2 & 0.95 & 0.82 & 1 & 0.99 & 0.992 \\
\hline $\mathrm{Fe}_{2} \mathrm{O}_{3}$ & 2.6 & 2.1 & 3.8 & 2.3 & 2.8 & 2.72 \\
\hline $\mathrm{CaO}$ & 3.1 & 3.9 & 2.3 & 3.5 & 3.1 & 3.18 \\
\hline MgO & 1.6 & 1.89 & 2.7 & 1.8 & 2.1 & 2.018 \\
\hline $\mathrm{Na}_{2} \mathrm{O}$ & 3.6 & 4.5 & 3.77 & 4.1 & 3.9 & 3.974 \\
\hline $\mathbf{K}_{2} \mathbf{O}$ & 2.3 & 2.45 & 2.15 & 2.4 & 2.3 & 2.32 \\
\hline $\mathbf{P}_{2} \mathbf{O}_{5}$ & 0.13 & 0.13 & 0.13 & 0.14 & 0.12 & 0.13 \\
\hline MnO & 0.08 & 0.16 & 0.14 & 0.12 & 0.12 & 0.124 \\
\hline LOI & 0.7 & 1.21 & $\mathbf{0 . 8 1}$ & 0.95 & 0.90 & 0.914 \\
\hline Total & 99.81 & 99.79 & 99.82 & 99.71 & 99.8 & 99.786 \\
\hline \multicolumn{7}{|c|}{ CIPW normative values } \\
\hline $\mathbf{Q}$ & 37.08 & 30.33 & 34.22 & 33.71 & 33.87 & 33.842 \\
\hline $\mathbf{C}$ & 6.88 & 3.74 & 6.27 & 5.32 & 5.63 & 5.568 \\
\hline Or & 13.59 & 14.47 & 12.70 & 14.1 & 13.58 & 13.688 \\
\hline $\mathbf{A b}$ & 30.46 & 38.07 & 31.90 & 34.33 & 33.47 & 33.646 \\
\hline Нy & 3.98 & 4.70 & 6.72 & 4.35 & 5.13 & 4.976 \\
\hline Mt & 0.26 & 0.52 & 0.45 & 0.41 & 0.41 & 0.41 \\
\hline Hm & 2.42 & 1.74 & 3.48 & 2.10 & 2.54 & 2.456 \\
\hline SUM & 94.68 & 93.61 & 95.77 & 94.32 & 94.68 & 94.612 \\
\hline \multicolumn{7}{|c|}{ Trace elements (Ppm) } \\
\hline $\mathrm{Cr}$ & 30 & 32 & 33 & 31 & 31 & 31.4 \\
\hline
\end{tabular}


The Geology, Geochemistry and Mineralogy of Beryl Mineralization in Zabara Area, South Eastern Desert, Egypt

\begin{tabular}{|c|c|c|c|c|c|c|}
\hline Cu & 41 & 38 & 34 & 39 & 38 & 38 \\
\hline Ni & 10 & 5 & 5 & 7 & 6 & 6.6 \\
\hline Zn & 45 & 29 & 25 & 37 & 33 & 33.8 \\
\hline Zr & 37 & 90 & 103 & 64 & 78 & 74.4 \\
\hline Ga & 14 & 54 & 12 & 35 & 27 & 28.4 \\
\hline Sr & 68 & 167 & 188 & 117 & 141 & 136.2 \\
\hline Y & 6 & 11 & 12 & 8 & 9 & 9.2 \\
\hline Rb & 36 & 52 & 57 & 44 & 48 & 47.4 \\
\hline V & 24 & 16 & 18 & 20 & 19 & 19.4 \\
\hline Nb & 2 & 4 & 5 & 3 & 3 & 3.4 \\
\hline Pb & 10 & 12 & 10 & 11 & 10 & 10.6 \\
\hline Ba & 731 & 536 & 594 & 633 & 621 & 623 \\
\hline
\end{tabular}

Table5. The averages of the major oxides of the studied schist rocks compared with averages of the major oxides of the schist at Wadi El Gemal area, SED, Egypt.

\begin{tabular}{|c|c|c|}
\hline S. No. & 1 & 2 \\
\hline $\mathrm{SiO}_{2}$ & 68.78 & 58.73 \\
\hline $\mathrm{Al}_{2} \mathrm{O}_{3}$ & 14.6 & 15.05 \\
\hline $\mathrm{TiO}_{2}$ & 0.992 & 0.85 \\
\hline $\mathrm{Fe}_{2} \mathrm{O}_{3}{ }^{{ }^{2}}$ & 2.72 & - \\
\hline $\mathrm{Fe}_{2} \mathrm{O}_{3}$ & - & 4.06 \\
\hline $\mathrm{FeO}$ & - & 5.14 \\
\hline $\mathrm{CaO}$ & 3.18 & 3.76 \\
\hline $\mathrm{MgO}$ & 2.018 & 2.50 \\
\hline $\mathrm{Na2O}$ & 3.974 & 4.92 \\
\hline $\mathrm{K}_{2} \mathrm{O}$ & 2.32 & 1.54 \\
\hline $\mathrm{P}_{2} \mathrm{O}_{5}$ & 0.13 & 0.14 \\
\hline $\mathrm{MnO}$ & 0.124 & 0.14 \\
\hline $\mathrm{LOI}$ & 0.914 & 3.31 \\
\hline Total & 99.786 & 100.15 \\
\hline
\end{tabular}

1- Average of the studied schist rocks (Zabara area), SED, Egypt.

2- Average of the schist rocksof Wadi El Gemal area (Omar, 2001).

From (Table 5) it is cleared that; the studied schist rocks have higher values of $\mathrm{SiO}_{2}, \mathrm{~K}_{2} \mathrm{O}$ and $\mathrm{TiO}_{2}$ than those in Wadi El Gemal area (Fig.29). On the other hand, Wadi El Gemal schist rocks have higher values of $\mathrm{Al}_{2} \mathrm{O}_{3}, \mathrm{MgO}, \mathrm{Na}_{2} \mathrm{O}, \mathrm{P}_{2} \mathrm{O}_{5}$ and $\mathrm{MnO}$ than those in Zabara area.

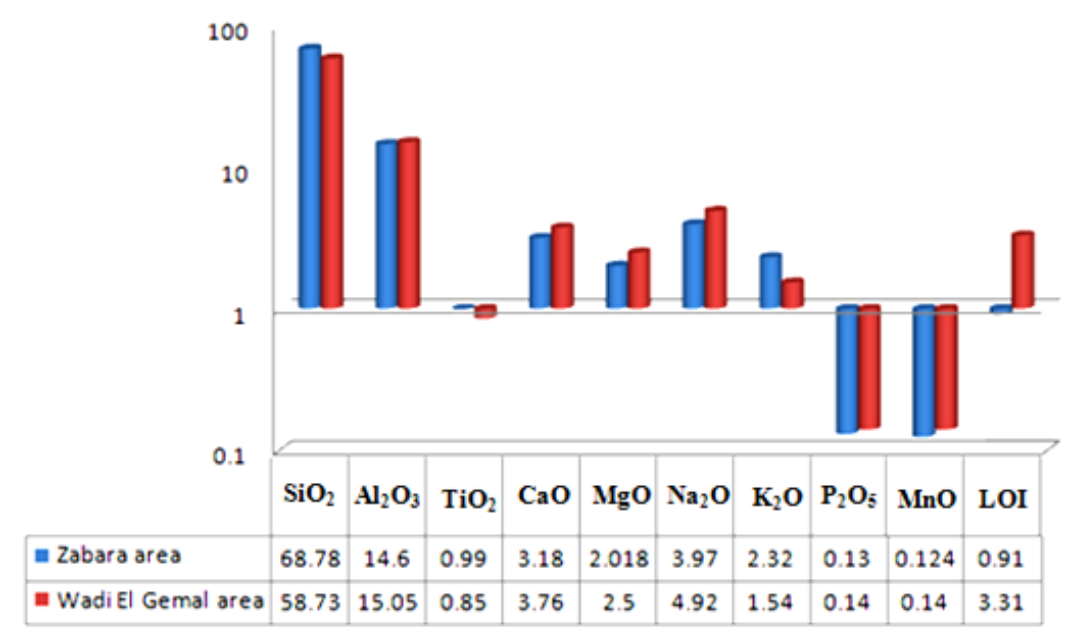

Fig 29. Bar-diagram showing the average of major oxides of schist rocks at Zabara and W. El Gemal areas, SED, Egypt. 


\section{CONCLUSION}

The present paper deals with the geology, mineralogy and geochemistry of beryl mineralization in Zabara area, south Eastern Desert Egypt. Zabara area is located at the northern part of the south Eastern Desert, the field observations revealed that the beryliferous zone concentrated along the contact between gneisses and schists, where the ancient mining was observed. The main structural feature of the area is a plunging anticline in a N30 E direction (Hassan and El-Shatoury1976). The gneiss rocks are exposed at the eastern and western sides of W. Zabara and they are affected by weathering. Vertical fractures and joints are occurred in the gneisses dominantly in N-S trends. The contact between the gneisses and schists is usually sharp contact. The schist rocks represent the most predominant rock unite within Zabara area. Garnet biotite schist that found in many places in this area and beryl disseminated in the phlogopite schist type. These schist rocks characterized by deformation and highly folded. The area is dissected by number of quartz veins, some of them are mineralized with beryl. These quartz veins having NE-SW direction. The beryl crystals characterized by small grain size, fractured crystals and pale green color.

The petrographic study of the beryl-bearing rocks in Zabara area revealed that the beryl mineralization were observed in quartz veins and phlogopite schist. Beryl in quartz veins occurred as a small prismatic crystal and characterized by high relief with green color. Also beryl characterized by cracking, parting and corroded by quartz.

The XRD analysis of beryl in W. Zabara area displayed beryl and quartz peaks, in case of quartzhosted beryl, suggesting that the beryl crystals were fractured and filled by quartz. In case of phlogopite schist-hosted beryl, it displayed beryl and muscovite peaks in X-ray diffractogram suggesting that the beryl crystals were fractured and filled by schist.

The ESEM (EDAX) analysis of beryl in Zabara area shows that the $\mathrm{Si}, \mathrm{Al}, \mathrm{Mg}$ and $\mathrm{Na}$ are the main constituents beside $\mathrm{Fe}, \mathrm{Ca}$ and $\mathrm{K}$. Ti appeared in quartz-hosted beryl, whereas $\mathrm{Ni}$ appeared in phlogopite schist-hosted beryl. The spectrometric survey among different rocks at Zabara area shows the radioactivity related to the gneisses.

The geochemical study of the gneiss rocks from Zabara area revealed that they have $\mathrm{Al}_{2} \mathrm{O}_{3}, \mathrm{MgO}$, $\mathrm{Na}_{2} \mathrm{O}$ and $\mathrm{P}_{2} \mathrm{O}_{5}$ contents higher than the gneiss rocks from Abu Rusheid area, while Abu Rusheid gneiss rocks have higher values of $\mathrm{SiO}_{2}, \mathrm{TiO}_{2}, \mathrm{~K}_{2} \mathrm{O}$ and $\mathrm{MnO}$ than those in Zabara area. By studying the schist rocks from Zabara area it is cleared that these schist rocks have higher values of $\mathrm{SiO}_{2}, \mathrm{~K}_{2} \mathrm{O}$ and $\mathrm{TiO}_{2}$ than those in Wadi El Gemal area. On the other hand, Wadi El Gemal schist rocks have higher values of $\mathrm{Al}_{2} \mathrm{O}_{3}, \mathrm{MgO}, \mathrm{Na}_{2} \mathrm{O}, \mathrm{P}_{2} \mathrm{O}_{5}$ and $\mathrm{MnO}$ than those in Zabara area.

\section{ACKNOWLEDGMENT}

The authors wish to thanks the Dr. Kamar M. S, Head of Abu Rusheid Project, Nuclear Materials Authority, Egypt, for interest as well as for help during field work.

\section{REFERENCES}

[1] Abdalla, H. M. and Mohamed, F. H. (1999): Mineralogical and geochemical investigation of emerald and beryl mineralization, Pan-African belt of Egypt: genetic and exploration aspects. J. Afr. Earth Sci., 28, p. 581-598.

[2] Abd Naby, H., and Frisch, W., (2002): Origin of Wadi Haimur-Abu Swayel gneiss belt, south Eastern Desert, Egypt: petrological and geochronological constraints. Precambr. Res. 113, p. 307-332.

[3] Abd Naby, H., Frisch, W., Hegner, E., (2000): Evolution of Pan- African Wadi Haimur metamorphic sole, Eastern Desert, Egypt. J. Metamorph. Geol. 18, p. 639-651.

[4] Clarke, S. P., Peterman, Z. E., and Heier, K. S., (1966): Abundance ofuranium, thorium and potassium, In: S.P. Clarke 4,J (Editor), Handbook of physical contacts, Geol. Soc. Am. Mem.97 sections 24, p. 521541.

[5] Egyptian General Petroleum Corporation-Conco Coral (1987): Geological map of Egypt scale 1:500,000.

[6] El Sayed, M. (1997):Pan-African magmatism in the Zabara district,Central Eastern Desert, Egypt; Geochemistry and Petrogensis. Qatar Univ. Sci. J., 17(2); p. 431-454.

[7] El-Bayoumi, R. M., (1980): Ophiolites and Associated Rocks of Wadi Ghadir, east of Gabal Zabara, Eastern Desert, Egypt (Ph.D. thesis). Cairo University, Egypt, 171pp. 
The Geology, Geochemistry and Mineralogy of Beryl Mineralization in Zabara Area, South Eastern Desert, Egypt

[8] Grubessi, O.; Aursicchio, C. and Castiglioni, A., (1990): The pharaoh's forgotten emerald mines. J. Gemmol., 2/3, p. 164-177.

[9] Grundman, G. and Morteani, G. (1993): Emerald formation during regional metamorphism: The Zabara, Sikait and Um Kabu deposits (Eastern Desert, Egypt). In: Thorweihe \& Schandelmeeir (eds.), Geoscientific Research in Northeast Africa, Balkema-Rotterdam, p. 495-498.

[10] Harrell, J. A., (2004): Archeological geology of the world's first emerald mine. Geoscience Canada 31 (2), p. 69-76.

[11] Hassan, M. A. and El-Shatoury, H. N,. (1976): Beryl occurrences in Egypt. Mining Geology. 26, p. 253262.

[12] Hassan, M. A., (1998): Tectonic evolution and deformational history of Zabara - Um Khariga area central Eastern Desert Egypt. Bull. Fac. Sci. Assiut Univ. 27 (2-F), 21-47p.

[13] International Atomic Energy Ageney (IAEA)., (1979): Gamma ray surveys in uranium exploration, Technical Report Series, paper No.186, 90pp.Vienna.

[14] Kamel, M., Youssef, M., Hassan, M., and Bagash, F., (2016): Utilization of ETM+ Landsat data in geologic mapping of wadi Ghadir-Gabal Zabara area, Central Eastern Desert, Egypt. The Egyptian Journal of Remote Sensing and Space Sciences v. 19, p. 343-360.

[15] Khaleal, F. M., (2016): Mineral chemistry and genesis of Wadi Abu Rusheid beryl, South Eastern Desert, Egypt. $11^{\text {th }}$ International Conference of Nuclear Science and Applications, Hurghada, Egypt. Feb.20-24. $29 \mathrm{pp}$.

[16] Mahmoud, M., (2009): Highlight on the geology, geochemistry and spectrometry of the muscovite granites at Wadi El-Gemal area, South Eastern Desert, Egypt, Ph.D. Thesis, Suez Canal University, Egypt, $227 \mathrm{pp}$.

[17] Omar, S. A., (2001): Characterization and evaluation of some beryl occurrences in the Eastern Desert, Egypt. Ph. D. Thesis, Cairo univ. Egypt, 258pp.

[18] Saleh, G. M., (1997): The potentiality of uranium occurrences in Wadi Nugrus Area, South Eastern Desert, Egypt. Ph.D. Thesis, Mansoura univ. Egypt, 171 pp.

[19] Shapiro, L. and Brannock, W. W., (1962): Rapid analysis of silicate, carbonate and phosphate rocks, U. S. Geol. Surv. Bull, 114 A, 56 P.

[20] Stuckless, J. S., Nokomo, I. T., Wenner, D. B. and Vantrump, G., (1983): Geochemistry and uranium favorability of the post-orogenic granites of the northwestern Arabian Shield, Kingdom of Saudi Arabia. Bull, Fac., Earth Sci., King Abdulaziz Univ.,6(1983), p. 195-209.

[21] Takla, M. A.; Surour, A. A.; and Omar, S. M. (2003): Mapping source of beryllium and genesis of some beryl occurrences in the Eastern Desert of Egypt. Annals of geological survey of Egypt.v. xxvi. p. 153-182.

Citation: Khaleal F. M., et.al, (2019)” The Geology, Geochemistry and Mineralogy of Beryl Mineralization in Zabara Area, South Eastern Desert, Egypt", Southeast Cameroon, International Journal of Mining Science (IJMS), 5(2), pp.18-34, DOI: http://dx.doi.org/10.20431/2454-9460.0502003

Copyright: (C) 2019 Authors. This is an open-access article distributed under the terms of the Creative Commons Attribution License, which permits unrestricted use, distribution, and reproduction in any medium, provided the original author and source are credited 